\title{
A COMPARATIVE STUDY OF PORTUGUESE AND SERBIAN TOURISM MARKETS
}

\author{
Nikola Minićl ${ }^{\star}$, Vitor Gomes Rodrigues ${ }^{2 \star}$, Catarina Ferreira Dias Dinis ${ }^{2}$, Ivana Stević ${ }^{2}$ \\ ${ }^{1}$ Singidunum University, Danijelova 32, Belgrade, Serbia \\ ${ }^{2}$ University of Aveiro, Campus Universitário de Santiago, 3810-193 Aveiro, Portugal
}

\begin{abstract}
:
As tourism presents one of Portugal's most valuable economy sectors, as well as the emerging sector in Serbian economy, the aim of this research is to provide an insight into Portuguese and Serbian tourism markets. In order to accomplish that, a statistical overview of the two mentioned tourism markets is conducted, as well as a comparison of available and potential tourism products. Furthermore, the paper includes a comparative analysis of several tourism policies based on each national strategic plan for tourism, as well as a brief review of their effectiveness. Bearing in mind that Serbia is a landlocked country, sun \& sea product of Portugal was analysed separately.
\end{abstract}

\section{Key words:}

statistical overview,

tourism products,

tourism policies,

national strategic plans for tourism, tourism analysis.

\section{INTRODUCTION}

A growing demand for tourism and leisure presents a global phenomenon that is directly linked to economic development, which significantly increases incomes of tourism destinations on both micro and macro level. Tourism presents one of the most important tourism sectors in Portugal, making a total of $15,7 \%$ share in the country's GDP in 2014 (WTTC, 2015a), with the anticipated rise of up to $17 \%$ in 2025 . On the other hand, tourism presents one of the emerging sectors of Serbian economy, making a total contribution of $6,1 \%$ in the overall country's GDP (WTTC, $2015 b$ ), with the anticipated rise of up to $7,2 \%$ in 2025 . The paper presents a comparative study of the two tourism markets, with the analysis of tourist arrivals and overnight stays, as well as implemented and planned tourism policies.

\section{NATIONAL TOURISM STRUCTURE}

\subsection{Portuguese Tourism Clusters}

As part of the national tourism strategies and with the aim to facilitate the grouping of different statistical data, Portuguese territory is organized in 7 distinctive regions, also known as NUTS II (Nomenclature of Territorial Units for Statistics) - Oporto and North, Centro, Lisbon, Alentejo, Algarve, Autonomous Region of Madeira and Autonomous Region of Azores (Figure 1). Although being covered by the tourism national polices, these regions are, in certain way, independent in terms of the development of strategies of their own territories, but being in line with those policies imposed by the national level/authority. On the other hand, national and regional policies have become complementary, in the way that they share common objectives, such as the development of Portugal as a tourism destination and the supply side management.

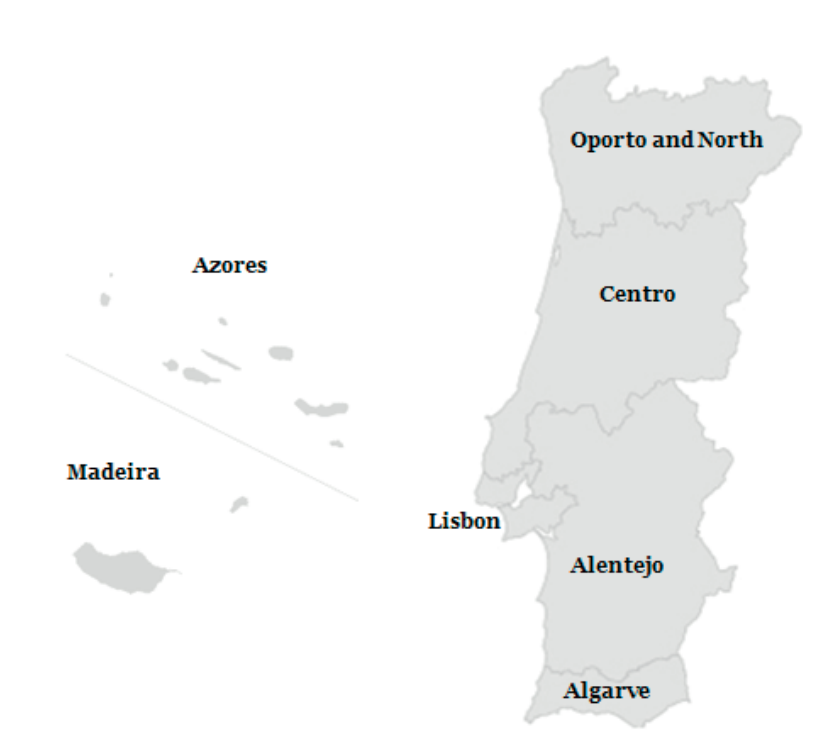

Figure 1. Portuguese tourism clusters Source: Own elaboration, based on NUTS II 


\subsection{Serbian Tourism Clusters}

Tourism Development Strategy proposes creation of four tourism clusters in order to better position Serbia as a tourism destination, as well as to create regional tourism brands, based on the geographical location, tourism resources and common traditions and customs. Those four clusters are (Strategija razvoja turizma Srbije, 2006, p. 13):

1. Vojvodina;

2. Belgrade;

3. South-western Serbia;

4. South-eastern Serbia.

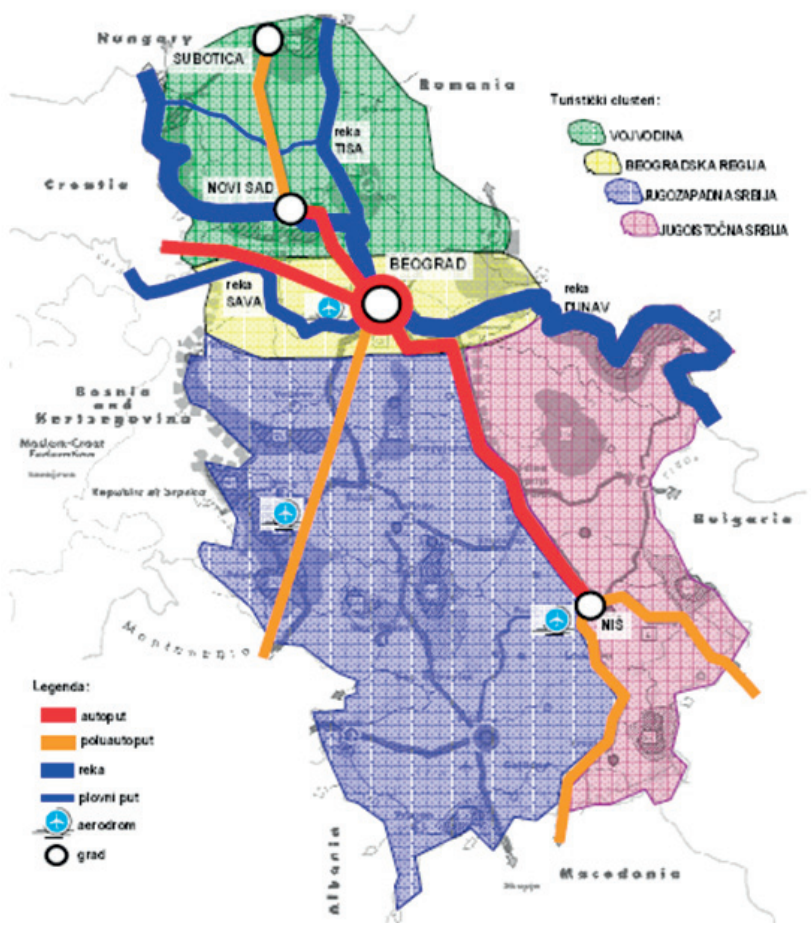

Figure 2. Tourism clusters as defined by Tourism Development Strategy

Source: Tourism Development Strategy (2006)

Each of these clusters had different strategic positioning, based on the available products, attractions, activities, and predicted experience. Out of these four defined clusters, only Belgrade is fully developed, while the other three have never been fully developed as planned by the strategy. However, for the purpose of statistics on the regional level, the country was divided into five statistical regions, which are further analysed in this paper. Those regions include as follows: (Uredba o nomenklaturi statističkih teritorijalnih jedinica, 2010):

1. Belgrade region;

2. Vojvodina region;

3. Šumadija and Western Serbia region;

4. Eastern and Southern Serbia region;

5. Kosovo and Metohija region.

\section{STATISTICAL OVERIEW}

\subsection{Portuguese Tourism Market}

Over the last decade, and with special emphasis on the last five years, Portugal has registered a continuous growth in the tourism industry. In practical terms, this means that, year after year, the tourism sector achieves new records, a fact proved by its performance during 2014, when the number of tourists surpassed 16 million ( $>6 \%$ than 2013) (Turismo de Portugal, 2015c) and the revenue exceeded the record of 10 billion euro (>6\% than 2013) (Turismo de Portugal, 2015e).

In order to better understand the sectors' performance, a brief analysis of its main indicators was conducted, with an emphasis on variables such as tourist flows (number of tourists), tourism revenue and overnight stays, throughout the period from 2010-2015.

Since 2010 until 2014, the number of tourists visiting Portugal rose at an average pace of $4 \%$ per year. Although with a slight decrease in 2012, driven by a decrease of domestic demand, it can be said that the global demand was systematic. During this period, the number of foreigners was constantly superior to the number of domestic tourists, as shown in Figure 3a, representing, on average, 55\% of the total number. Regarding the foreign tourists, it is interesting to underline the most represented outbound markets. The top outbound markets, representing approximately and on average $33 \%$ of the total number of tourists are: (1) United Kingdom; (2) Spain; (3) France; (4) Germany; and (5) Brazil.

Tourism revenue is an economic indicator directly associated with the number of tourists. Achieving 10.4 billion euro in 2014, the tourism revenue in Portugal also registered a substantial increase during the given period, growing at an average rate of $6 \%$ per year. Using the same analysis pattern, five outbound markets with the highest expenditure are emphasised. In this case, it is necessary to point out that in 2010 and 2011, Brazil was part of the top five, but since 2012 was surpassed by Angola. In comparison with the previous indicator, this group has higher representativeness, accounting for $62 \%$ of the total number: (1) France; (2) United Kingdom; (3) Spain; (4) Germany; and (5) Angola.

By observing the overnight stays chart (Figure 3b), almost an instant conclusion is that there is great superiority of the foreign demand. During the given period, international tourists were responsible for $68 \%$ of total overnight stays, which contributed to a new record of 46.1 million, in 2014. Once again, five markets were highlighted: (1) United Kingdom; (2) Germany; (3) Spain; (4) France; and (5) Holland.

On the other hand, so as to comprehend the tourist behaviour within the Portuguese territory, a brief analysis of tourist preferences was carried out at the level of Portuguese regions. Using the statistical data, it was concluded that Lisbon, Algarve and Oporto and North were the main regions visited during 2014, although Madeira emerges as the third largest region in terms of overnight stays (Figure 4). The combined contribution of Lisbon, Algarve and Oporto and North reaches $71 \%$ of the total number of tourists. When it comes to overnight stays, Algarve, Lisbon and Madeira totalize $75 \%$, especially owning to a better performance related to the average stay. On the other side, Azores and 

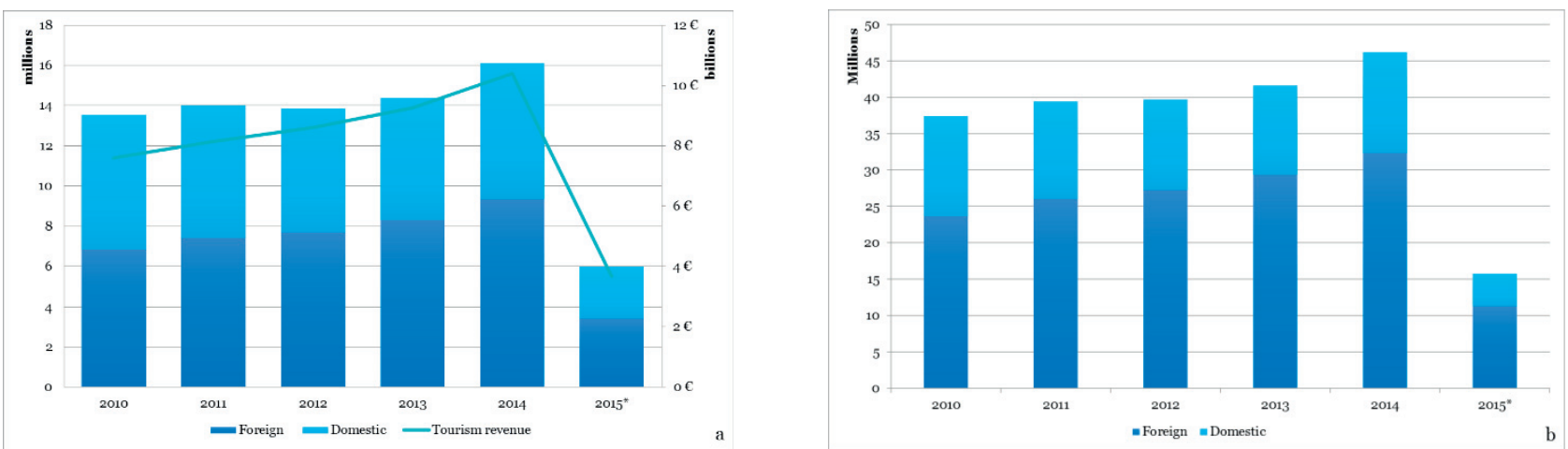

Figure 3. Domestic and foreign tourist flows and tourism revenue (left) and overnight stays (right)

Source: Own elaboration, based on Turismo de Portugal (2014b, 2014c, 2015c, 2015d, 2015e, 2015f)

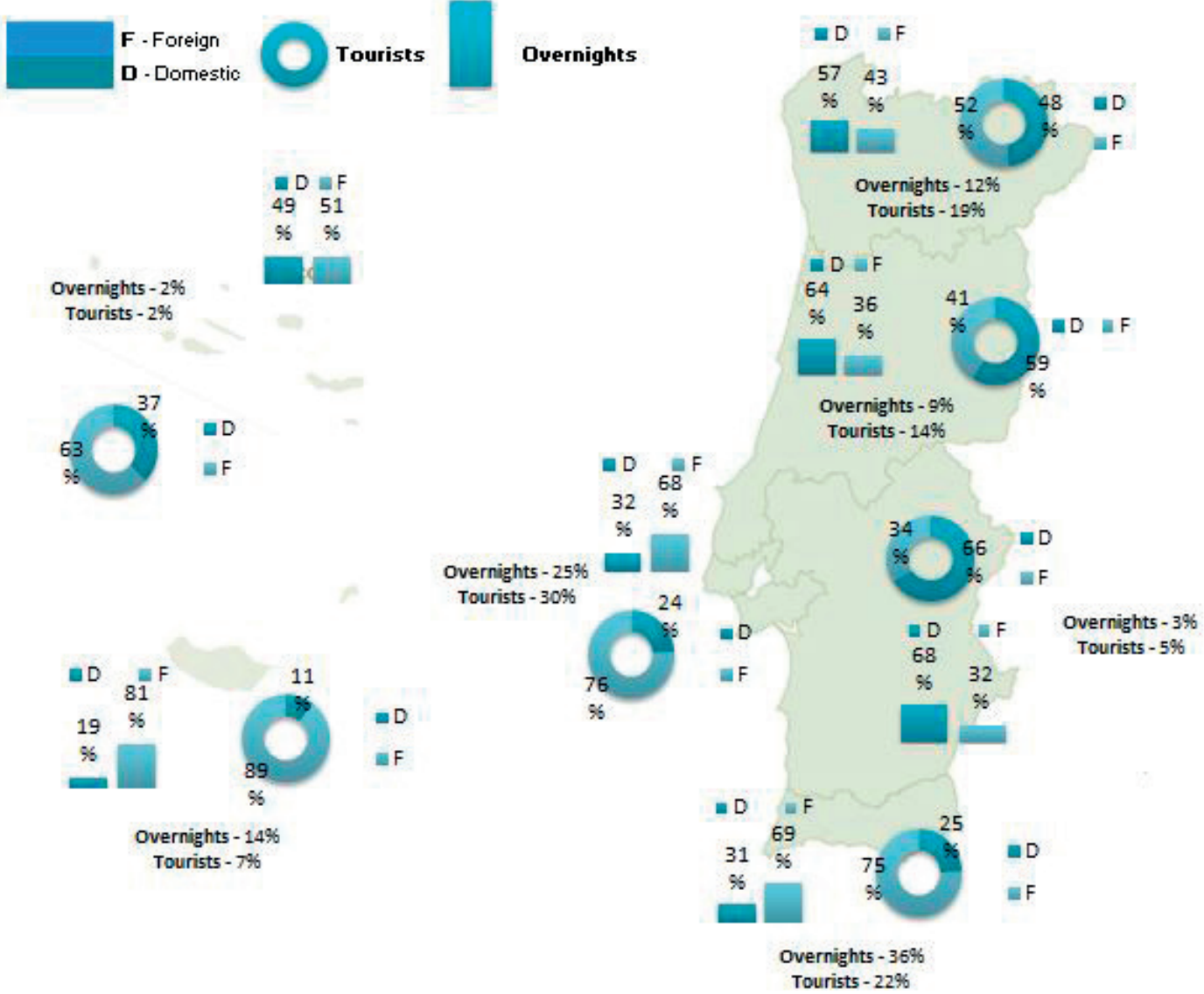

Figure 4. Tourist flows and overnight stays by regions in 2014

Source: Own elaboration, based on Dinis (2013) and Silva (2015)

Alentejo arise as the regions with lowest percentage, representing altogether only $7 \%$ of the total number of tourists and $5 \%$ of the total number of overnight stays.

\subsection{Serbian Tourism Market}

In 2014, Serbia recorded 2.196.268 visitors, which presents a slight decrease compared to 2013 (Republički zavod za statistiku, 2015). Domestic tourism recorded 1.163 .536 visitors (decrease $8,4 \%$, share $53 \%$ in total number of visitors), while international tourism recorded 1.08 .732 visitors (increase $11,6 \%$, share $47 \%$ ). Figure 5 shows the data from 2010 until November 2014. It can be seen that tourist flows were increasing throughout the 4 year period (2010 to 2013) and slightly dropped by the end of 2014, due to the decrease of national tourism flows, despite the increase of international visitor flows. As for the country of origin, the five outbound markets with the largest number of foreign visitors are: (1) Bosnia \& Herzegovina; (2) Slovenia; (3) Croatia; (4) Montenegro; and (5) Germany. It should also be noted that there has been an increase of arrivals from Bulgaria, Russia, Turkey and Greece in recent years. The tourists from Portugal recorded 2.775 arrivals in 2014, and 1.337 during the period January-July 2015. 

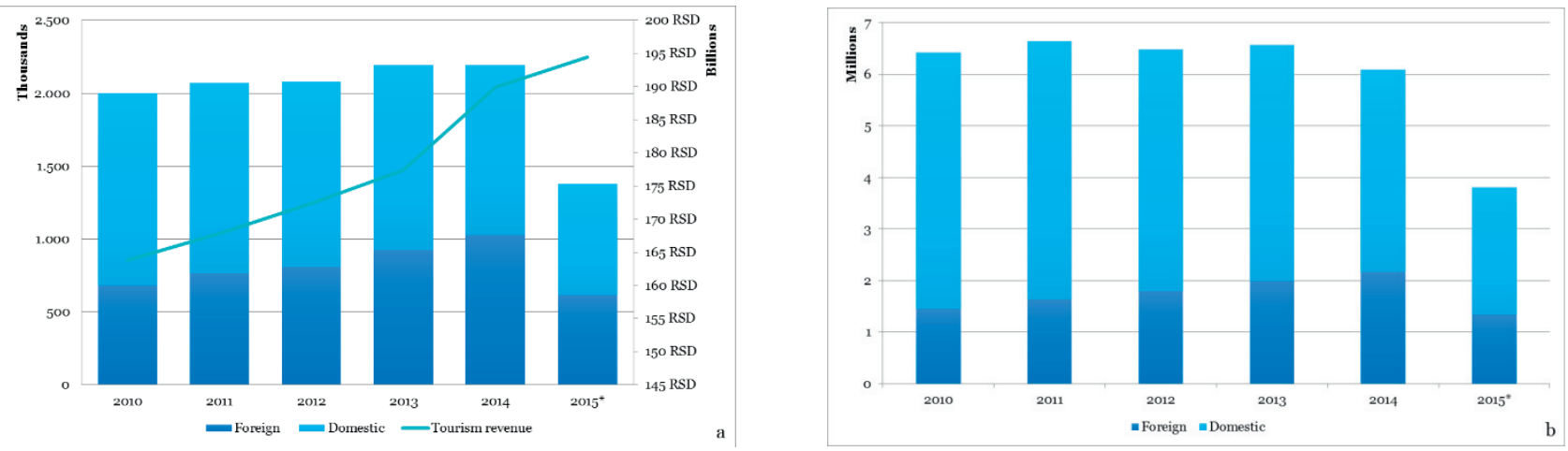

Figure 5. Domestic and foreign tourist flows and tourism revenue* (left) and overnight stays (right)

${ }^{*}$ Data for tourist flow in 2015 is given for period January-July 2015, while tourism revenue is an estimate for 2015. RSD - Serbian dinar. Source: Own elaboration, based on data from Statistical Office of the Republic of Serbia for tourist flows and overnight stays (2015) and The World Travel \& Tourism Council for tourism revenue (2015)

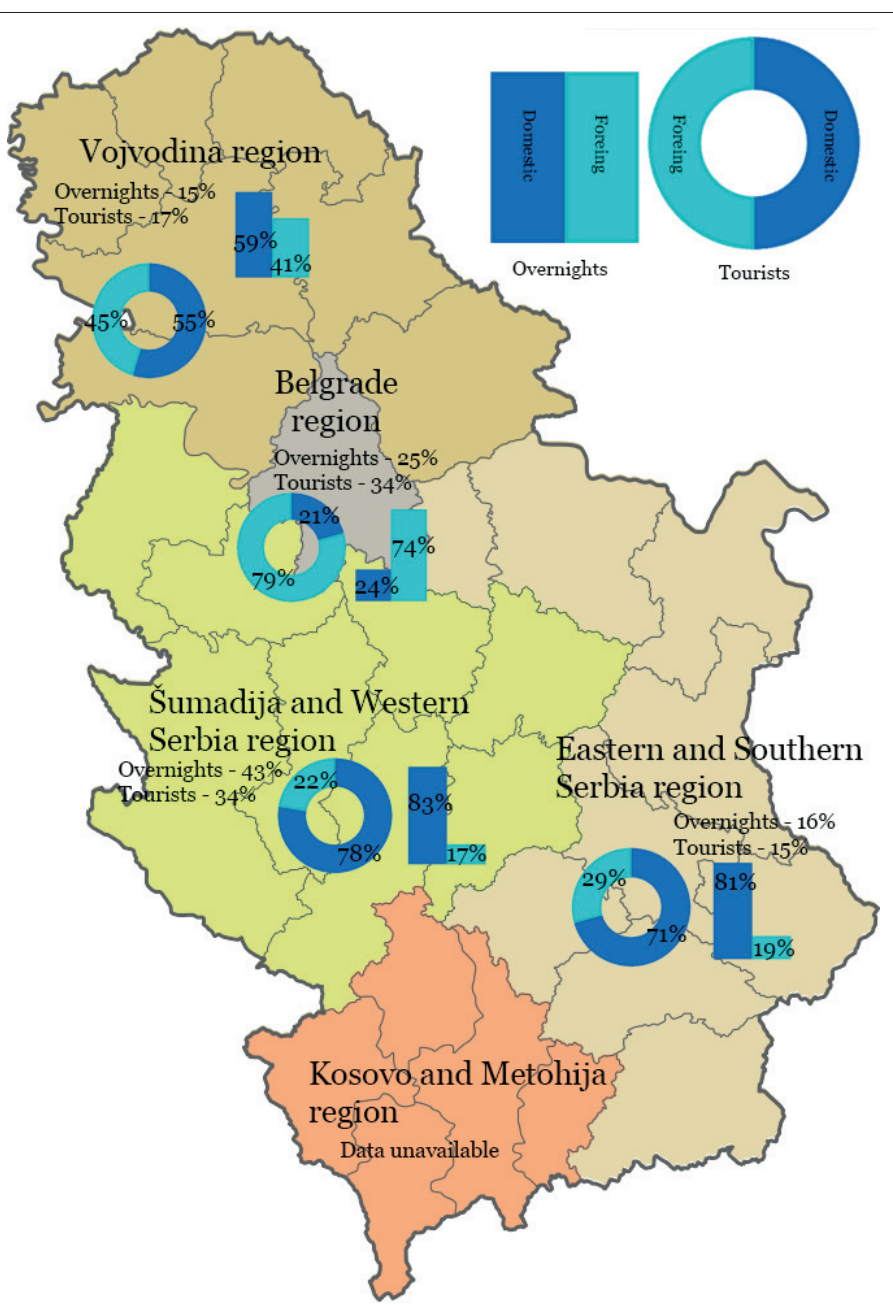

Figure 6. Tourist flows and overnight stays by regions in 2014

Source: Own elaboration, based on data from Statistical Office of the Republic of Serbia (2015)

In 2014, Belgrade region recorded an increase in the number of visitors of $+4,8 \%$. Besides Belgrade, only Vojvodina recorded an increase in the number of arrivals $(+7,0 \%)$, while the other two regions, Šumadija and Western Serbia and South and Eastern Serbia recorded a decrease of $6,8 \%$ and $1,6 \%$ respectively.

In terms of overnight stays, domestic tourists were dominant in all regions except for Belgrade, amounting to 3.925.221 of overnight stays (3,4 nights per tourist), while foreign tourists amounted to 2.161.054 of overnight stays (or 2,1 night per tourist), making 6.086 .275 of overnight stays in total. Five outbound markets with the largest amount of overnight stays are: (1) Bosnia \& Herzegovina; (2) Russia; (3) Montenegro; (4) Croatia; and (5) Germany. Tourists from Portugal recorded 6.869 overnight stays in 2014, and 3.678 during the period January-July 2015. 


\section{TOURISM OFFER}

\subsection{Portuguese Tourism Products}

Due to the diversified territory with vast resources, Portuguese authorities were able to develop ten main strategic products during the period between 2007 and 2015:

- Sun and Sea;

- City Breaks;

- Gastronomy and Wine;

- Golf;

- Meetings Industry;

- Health and Wellness;

- Nature Tourism;

- Cultural and Scenic Touring;

- Nautical Tourism;

- Resorts and Residential Tourism.

The study of each strategic product per region allowed to understand their stage of development, through the use of a proper matrix, (Ministry of Economy and Employment, 2013): (1) Emergent, (2) Complementary, (3) Under Development or (4) Consolidated.

According to the above -given Portugal tourism clusters, Sun and Sea is a consolidated product in the Algarve Region, being under development in Madeira. The other regions are in a secondary phase (Complementary) with the exception of Azores where it has no expression; City Break is a primary product in Lisbon and in Oporto and North (mainly in Oporto city) it is under development; Gastronomy and Wine is a Complementary Product in seven regions, thanks to a great variety of unique gastronomic resources; Golf has its main expression in Algarve, being Lisbon Under Development and Madeira and Oporto and North Complementary. Meetings Industry is Consolidated mainly in Lisbon city, and has secondary expression in Algarve and in Oporto and North (mainly Oporto city) is a Complementary product; Health and Wellness has a major impact in Oporto and North and in Centro, being at its second stage in Lisbon, Algarve and Madeira; Nature Tourism is Consolidated in Azores and Madeira, Under Development in Alentejo, Centro, Oporto and North, Algarve and Lisbon; Cultural and Scenic Touring is a Consolidated Product in Lisbon, Oporto and North, Centro, Madeira and Alentejo, being Under Development in Azores and Complementary in Algarve; Nautical Tourism in Under Development in Alentejo, Algarve, Lisbon, Madeira and Azores and Emergent in Oporto and North; Resorts and Residential Tourism is a Consolidated Product in Algarve, Under Development in Lisbon and Emergent in Madeira and Alentejo (Ministry of Economy and Employment, 2013).

\subsection{Serbian Tourism Products}

Tourism Development Strategy has defined a group of tourist products of special interests as potential development drivers, whose eventual commercialization could be applied to other investment and technologically demanding products. These products are the following (Strategija razvoja turizma Srbije, 2006):

- City break;

- Roundtrips (Touring);

- Business tourism + MICE;
- Health tourism (Spa/wellness);

- Mountain and lake holidays;

- Nautical tourism;

- Events;

- Rural tourism;

- Special interests.

City break, which includes sightseeing, shopping, museums and galleries, festivals and other events, as well as MICE (Jovanović, 2013, p. 93) is bound to larger cities, such as Belgrade and Novi Sad, which are defined as primary city breaks and MICE destinations, while Niš, Kragujevac and Subotica are secondary destinations. According to the National Tourism Organization of Serbia, 581 events were registered in 2010 (Jovanović, 2013, p. 151), which makes the events one of the main tourism products. There are already several worldwide festivals, such as Dragačevo trumpet festival in Guča, EXIT festival in Novi Sad, Belgrade Beer Fest and Nišville Jazz Festival in Niš.

As for roundtrips (or touring), wine and cultural routes emerge as the main products. The main vineyard regions are along the three Morava Rivers (South, Western and Great) and Sava, Danube and Tisa, with one along the Timok River in Eastern Serbia. The main wine routes are (Turistička organizacija Srbije, 2013a): Palić wine route, Fruška gora wine route, Vršac wine route, Smederevo wine route, Oplenac wine route, Negotin wine route, Knjaževac wine route and Župa wine route. The main products of cultural routes are (Turistička organizacija Srbije, 2013b): Route of the Roman emperors, Transomanica and Fortress on the Danube, which present three routes through three periods of Serbian history. Besides these three, potential cultural routes could be: Ibar zone of medieval heritage, and Morava zone of antic times and medieval heritage (Maksin, 2012, p. 173).

With over 1.000 springs of cold and warm mineral water (Turistička organizacija Srbije, 2013c), and over 53 thermal localities, health tourism presents one of the main tourism products that should be further developed, with Vrnjačka Banja as the primary destination, and Sokobanja, Jošanička Banja, Banja Koviljača and Prolom Banja as alternative destinations. For mountain holidays, the Strategy defined Kopaon$\mathrm{ik}$, Tara and Zlatibor as the main destinations, and Đerdap Lake as the main lake holiday destination. Besides Đerdap Lake, the river Danube is defined as the main nautical tourism destination, with Sava and Tisa as alternatives.

Based on a study conducted in 2008 for the Framework of sustainable development of rural tourism in Serbia, the following regions were defined and studied in detail, which could represent the main rural tourism products (Jovanović, 2013, p. 115): Eastern Serbia (Pirot, Knjaževac, Zaječar, Dimitrovgrad and Negotin); Lower Danube (Veliko Gradište, Golubac, Majdanpek and Kladovo); South Banat (Alibunar, Bela Crkva, Kovin and Vršac) and Central Serbia (Valjevo, Ljig, Gornji Milanovac, Kosjerić and Mionica).

\section{NATIONAL TOURISM REGULATION AND STRATEGY}

\subsection{Tourism Regulation in Portugal}

Portuguese tourism sector exerts great impact not only in economic terms, but also within the social framework, being an indispensable tool for regional and national development 
(Fazenda, Silva, \& Costa, 2008). Tourism sector is integrated within the Ministry of Economy, in a smaller structure called Tourism Secretary of State. Turismo de Portugal, I.P. is known as the maximum authority, being responsible for management and stimulation of tourism industry. Identified as a public entity, its main obligations include the elaboration of Portugal Tourism Policies, but also the promotion and enhancement of the national tourism activity.

As described in the Decree-Law 191/2009, dated August 17th, the National Tourism Policy has the following primary objectives (Ministry of Economy and Innovation, 2009): (i) the increase of tourist flows, average stay and average spending of domestic and foreign tourists; (ii) the contribution to social and economic development of the country, employment generation, GDP growth and decrease of regional disparities; (iii) the reinforcement of the tourism regional organization, in order to provide a better understanding between the local communities and different stakeholders; (iv) access improvement of tourism benefits to the residents; (v) better accessibilities to handicap or disabled individuals; (vi) the stimulus to international competitiveness of tourist activity through a qualified supply side and through innovation and creativity; (vii) the development of favourable conditions to enhance private investment in tourism; (viii) the development of the national tourism identity; (ix) the incentive to create public-private partnerships; (x) introduction of compensatory mechanisms to local communities, due to the use of the territory for tourism purposes.

The document "Turismo 2020 - Cinco princípios para uma ambição" (five principles to an ambition), which defines a wide range of policies and strategies for the tourism sector for the period between 2016 and 2020, replaces the National Strategic Plan for Tourism (2007-2015) and was elaborated with the aim of changing the existing paradigms of "a prescriptive, closed and state plan" (Tourism Secretary of State, 2015). This document defined a very clear objective for Portugal: make it the most agile and dynamic destination in Europe, always taking into account competition and qualification issues. In that sense, this ambition requires that Portugal will:

- have to be a sustainable destination with high quality patterns;

- be a destination with very competitive enterprises;

- turn in an entrepreneur destination;

- become interconnected to the rest of the world;

- be managed in an effective way;

- be an unforgettable destination.

Furthermore, the ambition of the new national tourism policy considers a set of five fundamental principles - People, Freedom, Openness, Knowledge and Collaboration. Those factors have influenced all previous public actions and it is certain that they will continue to make the difference in order to turn Portugal into an excellence destination. In this sense, all the strategies of this new Plan intend to create a dynamic and agile destination, to grow faster than the main competitors and be more competitive (Tourism Secretary of State, 2015).

\subsection{Tourism Regulation in Serbia}

In Serbia, tourism related regulations, policies and laws fall under the authority of the Ministry of Trade, Tourism and Telecommunications. The ministry is further divided into sectors, among which the tourism sector operates in the tourism area. Its responsibility is to perform actions that relate to (Ministarstvo trgovine, turizma i telekomunikacija, 2015): (i) Implementation of the Tourism Law and Tourism Development Strategy on the national level; (ii) Monitoring and analysis of the system solutions, law regulations and economic policy measures for operation and development of the tourism economy; (iii) Proposition of measures for tourism product and services' quality improvement and tourism offer competitiveness; (iv) Implementation of the adopted master plans; (v) Monitoring of the development, proposition of measures and implementation of activities for education and training of tourism workers, with the aim of increasing the employment rates; (vi) Integrated planning of tourism development and development of tourism related activities; etc.

In 2006, the Government of the Republic of Serbia adopted the Tourism Development Strategy for the period until 2015. This is the third document of this kind to be adopted. In 1986, the Government adopted the Concept of Tourism Development until 2000 and in 1999 the Tourism Strategy with the development goals until 2010 and the vision until 2020. According to Article 6, Paragraph 2 of the Tourism Law (Strategija razvoja turizma Srbije, 2006, p. 6 ), the objectives of the Serbian Tourism Development and tourism interests of the Republic of Serbia are the following:

1. Stimulating the economic growth, employment rates and residents' life quality through international tourism development;

2. Ensuring the development of positive national image at the international level;

3. Ensuring long-term protection and integrated management of natural and cultural resources, which contributes to sustainable tourism development;

4. Ensuring international quality standards for tourism consumers' protection in line with the contemporary European practices.

Within the tourism strategy, the Ministry of Trade, Tourism and Telecommunications (2006) has developed a very complete and thorough Strategic Marketing Plan at the national level, positioning each tourism region and discussing each tourism product, mentioned in the Chapter 4.2. Marketing goals are defined as follows (Strategija razvoja turizma Srbije, 2006, p. 25):

1. to position Serbia as a tourism destination at the global tourism market;

2. use the maximum sales efforts to increase multiple times the number of foreign visitors and domestic tourism traffic, in line with the life standard capacities of the country's population;

3. to establish and operationalize country's marketing system at the national, regional and local levels.

\section{CONCLUSION}

There is space for further tourism development in both of the surveyed countries, and each should define development perspectives. As for Serbia, a new tourism development strategy should be adopted, and steps should be taken towards implementation of aims and tasks defined, and further improvement of its infrastructure, including activation of other airports in the country, especially in the western part like Užice and Kraljevo. Also, Serbia should particular- 
ly define its primary outbound markets towards which further marketing plans would be aimed. Regarding Portugal's future strategic actions, and bearing in mind that Portugal is a destination extremely dependent on the so called "traditional outbound markets" (e.g. United Kingdom, Spain, France), it's imperious to look forward to new emergent markets such as the People's Republic of China, India and Russia, which can add a significant value to the Portuguese tourism and economic sectors. Besides a closer look to the outbound markets, the authorities of both countries should continue to enhance promotion campaigns, with charming strategies, in order to increase the number of visitors and reinforce human resources training actions, becoming more effective and efficient to better understand the needs of visitors. To conclude, it's also fundamental to captivate new private investment to strengthen tourism offer, without neglecting the legislative and supervisory role of the state, which brings us to the necessity of establishing equilibrium between these two sides.

\section{REFERENCES}

Dinis, C. (2013). Investimento público e desenvolvimento local no norte de Portugal, Dissertação de Mestrado. Aveiro: Universidade de Aveiro.

Fazenda, N., Silva, F., \& Costa, C. (2008). Política e planeamento turístico à escala regional: o caso da Agenda Regional de Turismo para o Norte de Portugal. Revista Portuguesa de Estudos Regionais, 18, 77-100.

Jovanović, V. (2013). Tematski turizam. Beograd: Univerzitet Singidunum.

Maksin, M. (2012). Turizam i prostor. Beograd: Univerzitet Singidunum.

Ministarstvo trgovine, turizma i telekomunikacija. (2015). Sektori Ministarstva. Sektor za turizam. Retrieved August 21, 2015, from http://mtt.gov.rs/sektori/sektor-zaturizam/?lang=lat

Ministry of Economy and Employment. (2013). Plano Estratégico Nacional do Turismo: Horizonte 2013-2015. Lisboa: Ministério da Economia e do Emprego.

Ministry of Economy and Innovation. (2009). Decree-Law no 191/2009, august 17th. Diário da República no 158/2009 - I série .

Republički zavod za statistiku. (2015). Turizam. Retrieved August 21, 2015, from http://www.stat.gov.rs/

Silva, M. (2015). Os resultados do Turismo 2014. Lisboa: Turismo de Portugal, I.P.
Strategija razvoja turizma Srbije. (2006). Službeni glasnik RS $91 / 2006$.

Tourism Secretary of State. (2015). Turismo 2020 - Cinco princípios para uma ambição. Lisboa: Ministério da Economia.

Turismo de Portugal. (2014a). Dormidas em estabelecimentos hoteleiros, aldeamentos e apartamentos turísticos e outros (2004-2013). Lisboa: Turismo de Portugal, I.P.

Turismo de Portugal. (2015a). Dormidas em estabelecimentos hoteleiros, aldeamentos e apartamentos turísticos e outros (2013-2014). Lisboa: Turismo de Portugal, I.P.

Turismo de Portugal. (2015b). Dormidas em estabelecimentos hoteleiros, aldeamentos e apartamentos turísticos e outros (2015). Lisboa: Turismo de Portugal, I.P.

Turismo de Portugal. (2014b). Hóspedes em estabelecimentos hoteleiros, aldeamentos e apartamentos turísticos e outros (2004-2013). Lisboa: Turismo de Portugal, I.P.

Turismo de Portugal. (2015c). Hóspedes em estabelecimentos hoteleiros, aldeamentos e apartamentos turísticos e outros (2013-2014). Lisboa: Turismo de Portugal, I.P.

Turismo de Portugal. (2015d). Hóspedes em estabelecimentos hoteleiros, aldeamentos e apartamentos turísticos e outros (2015). Lisboa: Turismo de Portugal, I.P.

Turismo de Portugal. (2014c). Receitas turísticas da rúbrica "Viagens e Turismo" da Balança de Pagamentos (créditos) (2004-2013). Lisboa: Turismo de Portugal, I.P.

Turismo de Portugal. (2015e). Receitas turísticas da rúbrica "Viagens e Turismo" da Balança de Pagamentos (créditos) (2013-2014). Lisboa: Turismo de Portugal, I.P.

Turismo de Portugal. (2015f). Receitas turísticas da rúbrica "Viagens e Turismo" da Balança de Pagamentos (créditos) (2015). Lisboa: Turismo de Portugal, I.P.

Turistička organizacija Srbije. (2013c). Banje i klimatska mesta. Retrieved August 19, 2015, from http://www.srbija. travel/destinacije/banje-i-klimatska-mesta/

Turistička organizacija Srbije. (2013b). Putevi kulture. Retrieved August 19, 2015, from http://www.srbija.travel/ kultura/putevi-kulture/

Turistička organizacija Srbije. (2013a). Putevi vina. Retrieved August 19, 2015, from http://www.srbija.travel/destinacije/putevi-vina/

Uredba o nomenklaturi statističkih teritorijalnih jedinica. (2010). Službeni glasnik RS 46/2010 .

WTTC. (2015a). Travel \& Tourism Economic Impact 2015 Portugal. The World Travel \& Tourism Council.

WTTC. (2015b). Travel \& Tourism Economic Impact 2015 Serbia. The World Travel \& Tourism Council. 